\title{
An MT1-MMP-PDGF receptor- $\beta$ axis regulates mural cell investment of the microvasculature
}

\author{
Kaisa Lehti, ${ }^{1,3}$ Edward Allen, ${ }^{1}$ Henning Birkedal-Hansen, ${ }^{2}$ Kenn Holmbeck, ${ }^{2}$ Yasuhiro Miyake, ${ }^{1}$ \\ Tae-Hwa Chun, ${ }^{1}$ and Stephen J. Weiss ${ }^{1,4}$ \\ ${ }^{1}$ Division of Molecular Medicine and Genetics, Department of Internal Medicine, University of Michigan, Ann Arbor, \\ Michigan 48109, USA; ${ }^{2}$ National Institute of Dental and Craniofacial Research, Bethesda, Maryland 20892, USA
}

Platelet-derived growth factor (PDGF)/PDGFRß-dependent investment of the vascular endothelium by mural cells (i.e., pericytes and vascular smooth muscle cells; VSMCs) is critical for normal vessel wall structure and function. In the developing vasculature, mural cell recruitment is associated with the functionally undefined expression of the type I transmembrane proteinase, membrane-type 1 matrix metalloproteinase (MT1-MMP). In this paper, using VSMCs and tissues isolated from gene-targeted mice, we identify MT1-MMP as a PDGF-B-selective regulator of PDGFR $\beta$-dependent signal transduction and mural cell function. In VSMCs, catalytically active MT1-MMP associates with PDGFR $\beta$ in membrane complexes that support the efficient induction of mitogenic signaling by PDGF-B in a matrix metalloproteinase inhibitor-sensitive fashion. In contrast, MT1-MMP-deficient VSMCs display PDGF-B-selective defects in chemotaxis and proliferation as well as ERK1/2 and Akt activation that can be rescued in tandem fashion following retroviral transduction with the wild-type protease. Consistent with these in vitro findings, MT1-MMP-deficient brain tissues display a marked reduction in mural cell density as well as abnormal vessel wall morphology similar to that reported in mice expressing PDGF-B or PDGFR $\beta$ hypomorphic alleles. Together, these data identify MT1-MMP as a novel proteolytic modifier of PDGF-B/PDGFR $\beta$ signal transduction that cooperatively regulates vessel wall architecture in vivo.

[Keywords: PDGF-B; PDGF receptor; MT1-MMP; pericytes; vascular smooth muscle cells; mural cells]

Received December 30, 2004; revised version accepted March 2, 2005.

During blood vessel development, nascent endothelial cell tubules are invested by an outer sheath of mural cells that play a critical role in controlling vascular wall structure and function (Gerhardt and Betsholtz 2003; Hoch and Soriano 2003). Largely based on ultrastructural analyses, the mural cell populations that surround arteries, arterioles, and veins in single or multiple layers are termed vascular smooth muscle cells (VSMCs), while the investing cells that more sparsely decorate venules and capillaries are termed pericytes (Jain 2003). Evidence to date indicates that the recruitment, proliferation, and maintenance of stable mural cell-endothelial cell interactions are dependent on an intact platelet-derived growth factor (PDGF)-B/PDGF receptor- $\beta$ (PDGFR $\beta$ ) axis (Betsholtz 2003; Gerhardt and Betsholtz 2003; Hoch and Soriano 2003). Indeed, PDGF-B or PDGFR $\beta$-null mice exhibit severe defects in both VSMC/pericyte number

\footnotetext{
${ }^{3}$ Current address: Departments of Virology and Pathology, Haartman Institute and Biomedicum Helsinki, University of Helsinki and Helsinki University Hospital, Helsinki, FIN-00014, Finland.

${ }^{4}$ Corresponding author.

E-MAIL sjweiss@umich.edu; FAX (734) 647-7950.

Article and publication are at http://www.genesdev.org/cgi/doi/10.1101/ gad.1294605
}

and function during late embryogenesis that combine to result in the generation of unstable blood vessels, edema, and lethal hemorrhage (Leveen et al. 1994; Soriano 1994; Lindahl et al. 1997; Hellström et al. 1999, 2001). While mice harboring hypomorphic PDGF-B or PDGFR $\beta$ alleles can survive into adulthood, mural cell number and function are nonetheless affected, resulting in an increasingly compromised vascular compartment (Tallquist et al. 2000, 2003; Enge et al. 2002; Lindblom et al. 2003; Bjanegård et al. 2004).

To date, the mechanisms by which the PDGF-B/ PDGFR $\beta$-initiated signal transduction cascade regulates mural cell function remain the subject of intense scrutiny. Following receptor ligation by PDGF-B, the PDGFR $\beta$ dimerizes, undergoes autophosphorylation, and recruits a diverse set of at least $10 \mathrm{SH} 2$ domaincontaining proteins that then activate multiple downstream cascades which serve to control migration and proliferation (DeMali et al. 1999; Hoch and Soriano 2003; Tallquist and Kazlauskas 2004). Independent of the specific roles that each of these downstream signal transduction cascades play in defining mural cell phenotype, PDGF-B/PDGFR $\beta$ effector function can be further modulated by interactions with accessory factors ranging from non-PDGF peptide growth factors and sphingolipids to 
cell adhesion molecules (Schneller et al. 1997; DeMali et al. 1999; Li et al. 2000; Hobson et al. 2001). Given established precedences that PDGF-B/PDGR- $\beta$ signaling is sensitive to transmodulation, we were intrigued by an earlier report that the investment of the developing aorta by primordial smooth muscle cells is associated with the mural cell-specific expression of the membrane-anchored metalloproteinase, MT1-MMP (Apte et al. 1997). This type I transmembrane protease is a member of a larger family of 25 matrix metalloproteinases (MMPs) whose function, until recently, had been ascribed largely to their ability to hydrolyze extracellular matrix components (Egeblad and Werb 2002; Seiki et al. 2003). With the realization that the MMP substrate repertoire extends beyond matrix-associated macromolecules, these proteinases have been shown to exert complex effects on a number of target cell populations (Egeblad and Werb 2002; Seiki et al. 2003). While MT1-MMP expression has not previously been linked to mural cell function, we now report that the catalytically active enzyme associates with the PDGFR $\beta$ in smooth muscle cells and specifically regulates PDGF-B-initiated signal transduction cascades. Further, MT1-MMP-deficient mural cells display attenuated PDGF-B-dependent cellular function in vitro and in vivo in a fashion similar, if not identical, to that observed in mural cells expressing PDGF-B or PDGFR $\beta$ hypomorphic alleles (Tallquist et al. 2000, 2003; Enge et al. 2002). Together, these data not only identify an unexpected role for MT1-MMP in regulating PDGF-B-PDGFR $\beta$ signaling, but also define a new requirement for MT1-MMP in the control of mural cell function and vessel wall architecture in vivo.

\section{Results}

\section{MT1-MMP-dependent regulation of VSMC function}

During embryogenesis, MT1-MMP is prominently expressed within smooth muscle cells of the prospective tunica media of developing large arteries (Apte et al. 1997). To determine whether MT1-MMP deficiency compromises arterial structure, aortas were harvested from 4- to 14-d-old wild-type and $M T 1-M M P^{-/-}$mice and histology was assessed by light and transmission electron microscopy (TEM). At post-natal day 4, a time point at which $M T 1-M M P$ wild-type and null mice are indistinguishable phenotypically (Holmbeck et al. 1999), the vessel wall of control mice displayed the classic array of single layers of juxtaposed vascular smooth muscle cells (VSMCs) separated by well-developed elastic laminae. In contrast, the medial layer of $M T 1-M M P^{-/-}$aortae were thinner, and distinguished by a markedly decreased density of VSMCs interposed between thin sheets of elastin (Fig. 1A,B). Despite the rarefied appearance of the MT1$M M P^{-/-}$aorta, the overall structure of the VSMC and overlying endothelium appeared comparable to wildtype cells by TEM (Fig. 1A; data not shown), and apoptotic indices were similar to those detected in wild-type tissue (i.e., $0.1 \%$ vs. $0.12 \% ; n=2$ ). While patterns of $M M P 2$ expression frequently parallel those of MT1-MMP
(Apte et al. 1997), aortae harvested from MMP2-null mice displayed no obvious structural defects (Fig. 1A,B).

In an effort to determine the possible molecular basis of the alterations observed in the $M T 1-M M P^{-/-}$arterial media, $M T 1-M M P^{+/+}$and $M T 1-M M P^{-/-}$VSMCs were isolated from the respective tissues, and early passage cultures established. Consistent with the comparable morphology of wild-type and $M T 1-M M P$-null VSMCs in situ, cultures of isolated MT1-MMP $P^{+/+}$and $M T 1-M M P^{-/-}$ VSMCs were indistinguishable as assessed by phase contrast microscopy or smooth muscle $\alpha$-actin staining despite the absence of immunodetectable MT1-MMP in the knockout cells (Fig. 1C).

Current evidence suggests that smooth muscle precursors recruited to the developing artery wall proliferate in response to mitogenic and chemotactic stimulation by locally expressed growth factors-particularly PDGF-B (Crosby et al. 1999; Hellström et al. 1999; Gerhardt and Betsholtz 2003). To determine if $M T 1-M M P^{-/-}$VSMCs are capable of mounting a normal response to growth factor stimulation, quiescent cultures were established under serum-free conditions and BrdU uptake monitored following the addition of PDGF-B, PDGF-A, FGF-2, IGF1 , TGF- $\beta$, EGF, or serum. Significantly, $M T 1-M M P^{-/-}$, but not $M M P 2^{-/-}$VSMCs exhibited a selective growth defect in response to PDGF-B with the proliferative index depressed by $\sim 70 \%$ (Fig. 1D). A small, but significant, increase in apoptosis was noted in PDGF-B-stimulated VSMCs (i.e., $1.9 \%$ in wild-type cells versus $6.7 \%$ in null cells) (data not shown), consistent with the ability of PDGF-B to induce cell death in growth-arrested cells (Kim et al. 1995). Further, the chemotactic response of $M T 1-M M P^{-/-}$VSMC to PDGF-B, but not serum or FGF2 , was ablated selectively (i.e., $20 \pm 8 \%$ of control for PDGF-B stimulation vs. $76 \pm 12 \%$ for FGF- 2 stimulation; mean $\pm 1 \mathrm{SD}, n=3$ ). While ECM composition can alter VSMC responses to growth factor stimulation /Owens et al. 2004), the PDGF-B-stimulated proliferative response of $M T 1-M M P^{-/-}$VSMCs remains depressed on either type I collagen, fibronectin, vitronectin, or an extract of basement membrane macromolecules (i.e., Matrigel) (Fig. 1E).

MT1-MMP-null VSMCs display a specific defect in PDGF-B-initiated signaling

PDGF-B signaling initiates a complex mix of both rapidacting and long-term effects on VSMC function (Fambrough et al. 1999; Hoch and Soriano 2003). In the earliest phases of the cellular response to PDGF-B stimulation, PDGFR $\beta$, the predominant PDGF receptor found in VSMCs, rapidly undergoes dimerization and autophosphorylation, hence leading to the initiation of multiple signal transduction pathways that regulate proliferative responses (Fambrough et al. 1999; Hoch and Soriano 2003; Tallquist et al. 2003). First, to determine if MT1$M M P$ deficiency affects PDGFR $\beta$ expression levels or PDGF-B-induced autophosphorylation, wild-type and null cells were incubated alone or with PDGF-B for 10 min. Following short-term stimulation, no differences 
A

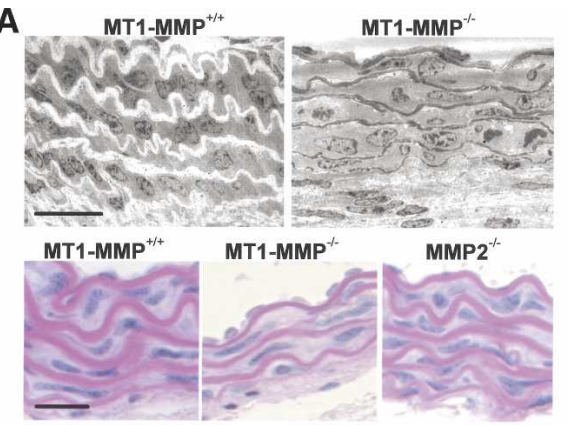

B

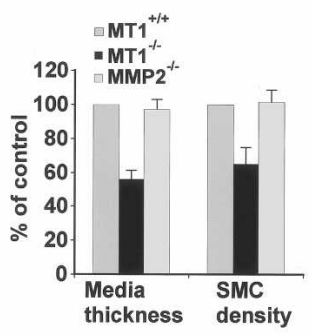

C

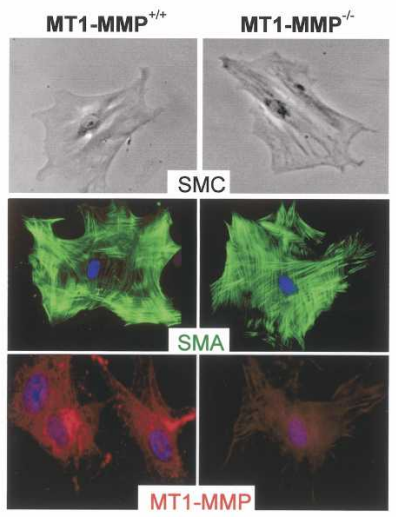

D

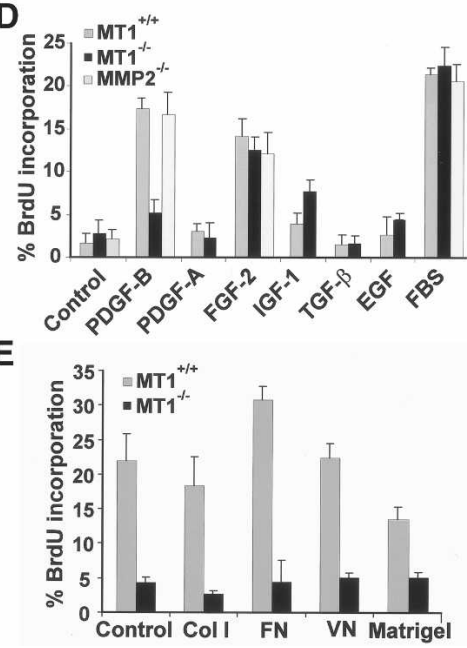

Figure 1. Characterization of $M T 1-M M P^{-/-}$VSMC morphology and mitogenic activity. (A) Aortic walls

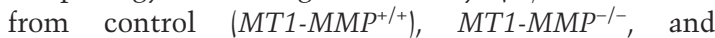
$M M P 2^{-/-}$mice were assessed by TEM (electron micrographs in the upper panel are from 4-d-old mice; bar, 10 $\mu \mathrm{m})$ or light microscopy (H\&E staining 14-d-old mice; lower panels, bar, $20 \mu \mathrm{m})$. Both analyses highlight the rarefied appearance of $M T 1-M M P^{-/-}$aortas, while the overall VSMC structure appeared comparable to wildtype cells by TEM. (B) Quantitative assessment of aortic wall VSMCs. Charts show relative values of average medial layer thickness measured from three different areas of thoracic aorta from 14-d-old mice $(n=4)$. VSMC density was determined by counting VSMC nuclei per cross-sectional area. The data are expressed as relative values compared with control littermates. Similar, if not identical, results were obtained at postnatal day 4 in comparisons between $M T 1-M M P^{+/+}$and $M T 1-M M P^{-/-}$aortae. (C) Morphology of isolated control (left) and MT1-MMP-null (right) VSMCs assessed by phase-contrast micrography (upper panel). $\alpha$ SMA and MT1-MMP content were monitored by immunohistochemistry. Nuclei were visualized by DAPI counterstaining. $(D)$ Semiconfluent cultures of wild-type (darkgray bars), $M T 1-M M P$-null (black bars), or $M M P$-2-null (light-gray bars) VSMCs were growth-arrested and exposed to PDGF-B, PDGF-A, FGF- 2 , IGF-1, TGF- $\beta$, EGF (30 ng/mL each, except TGF- $\beta$ at $10 \mathrm{ng} / \mathrm{mL}$ ) or $10 \%$ FBS as indicated. Control cells were incubated in cell culture medium alone. BrdU-incorporation was assessed after $24 \mathrm{~h}$. Results are expressed as mean $\pm 1 \mathrm{SD}(n=3)$. (E) Littermate control (gray bars) or MT1-MMP-null (black bars) VSMCs were serum-starved and replated in the presence of $30 \mathrm{ng} / \mathrm{mL}$ PDGF-B on uncoated plastic surfaces, or on surfaces coated with $100 \mu \mathrm{g} / \mathrm{mL}$ type I collagen, Matrigel, fibronectin, or vitronectin. BrdU-incorporation was assessed as above.

were observed between PDGFR $\beta$ levels in either whole cell lysates or at the cell surface (Fig. 2A). Furthermore, the phosphotyrosine content of PDGFR $\beta$ recovered from PDGF-B-stimulated $M T 1-M M P^{+/+}$or $\quad M T 1-M M P^{-/-}$ VSMCs was comparable (Fig. 2A). Unexpectedly, however, MT1-MMP was found in association with the PDGFR $\beta$ in immunoprecipitates recovered from cells cultured in either the absence or presence of PDGF-B (Fig. 2B), thus, raising the possibility that the metalloprotease participates directly in downstream signaling events.

In VSMCs, PDGF-B-initiated proliferation has been linked to the activation of both the ERK1/2 and PI3K/ Akt pathways (Fambrough et al. 1999; Hoch and Soriano 2003; Tallquist and Kazlauskas 2004). To assess the integrity of PDGF-B signaling cascades in wild-type versus MT1-MMP-null VSMCs, cells were growth-arrested in serum-free media and stimulated with PDGF-B, FGF-2, or serum. Under these conditions, MT1-MMP ${ }^{+/+}$VSMCs responded to PDGF-B stimulation by activating ERK-1 and ERK-2 as well as Akt (Fig. 2C). In contrast, MT1$M M P^{-/-}$cells displayed a significantly attenuated response to PDGF-B such that at $60 \mathrm{~min}$ post-stimulation, pERK1/2 and pAkt levels returned to baseline levels of detection (Fig. 2C). In three experiments, pERK $1 / 2$ and Akt levels were decreased markedly by $62 \pm 5 \%$ and $79 \pm 6 \%$ at $30 \mathrm{~min}$ and $76 \pm 6 \%$ and $86 \pm 5 \%$ at $60 \mathrm{~min}$, respectively $(n=3$; mean $\pm 1 \mathrm{SD})$. Signaling responses to either PDGF-A or PDGF-AB were comparable in wildtype and MT1-MMP-null cells (data not shown). In contrast, consistent with a selective defect in PDGF-B signaling, wild-type, but not MT1-MMP ${ }^{-/-}$, VSMCs underwent PDGF-B-initiated changes in actin polymerization near the cell surface to produce membrane ruffles and lamellipodia critical to the support of migratory and chemotactic responses (Fig. 2C; Tallquist and Kazlauskas 2004). Of note, despite the inability of $M T 1-M M P^{-/-}$ VSMCs to respond effectively to PDGF-B stimulation, both FGF-2-dependent and serum-dependent ERK1/2 and Akt activation proceeded comparably to wild-type cells (Fig. 2D). While MT1-MMP could conceivably alter PDGF-B signaling by either hydrolyzing ECM macromolecules to generate bioactive fragments, solubilizing membrane-tethered ligands, or activating endogenously derived growth factors (Egeblad and Werb 2002; Seiki et al. 2003), a required role for the metalloprotease in wildtype cells was not abrogated by culturing VSMCs on polylysine-coated surfaces in the presence of cyclohexamide (i.e., to prevent MT1-MMP access to cell-derived or exogenously supplied ECM targets) nor was the defect in $M T 1-M M P^{-/-}$VSMCs rescued by either coculturing with wild-type cells or supplementing cultures with degraded collagen or bioactive TGF- $\beta$ (i.e., products of MT1-MMP-mediated hydrolysis of collagen or latent 
Lehti et al.

Figure 2. Defective PDGF-B initiated signaling in MT1$\mathrm{MMP}^{-/-}$VSMCs. (A) Control or MT1-MMP $P^{-/-}$VSMCs were stimulated with PDGF-B for $10 \mathrm{~min}$ and cell extracts prepared for analysis. (Upper panel) Total lysates $(25 \mu \mathrm{g} /$ lane $)$ of control or PDGF-B-stimulated VSMCs were analyzed by Western blotting for MT1-MMP and PDGFR $\beta$. (Lower panel) Cell lysates (200 $\mu \mathrm{g} / \mathrm{sample})$ were immunoprecipitated with antibodies against PDGFR $\beta$. For the detection of cell surface PDGFR $\beta$, cells were incubated with Sulfo-NHS-biotin prior to immunoprecipitation. Similar levels of surface-biotinylated and autophosphorylated PDGFR $\beta$ were detected using peroxidase-conjugated streptavidin and antibodies against phospho-tyrosine residues $(\mathrm{pY})$, respectively, in precipitates from control or MT1-MMP-null VSMCs. $(B)$ PDGFR $\beta$ immunoprecipitates were prepared and separated in SDS-PAGE under nonreducing conditions. Western blotting with antibodies against MT1-MMP revealed its coprecipitation with PDGFR $\beta$ from wild-type cells. The total levels of PDGFR $\beta$ as detected with goat antiPDGFR $\beta$ antibodies were comparable in control and $M T 1-M M P$-null VSMCs. In a reversed experiment, PDGFR $\beta$ was detected from MT1-MMP immunoprecipitates (data not shown). (C) Growth-arrested control or $M T 1-M M P^{-/-}$VSMCs (cultured on type I collagen) were stimulated with PDGF-B $(10 \mathrm{ng} / \mathrm{mL})$ for $0-120 \mathrm{~min}$ as indicated. (Upper panel) Phosphorylated forms of AKT (pAKT) and ERK (pERK) were detected in VSMC lysates (25 $\mu \mathrm{g} /$ lane). Total ERK1/2 proteins served as loading controls. (Lower panel) Control and MT1-MMP $P^{-/-}$ VSMCs were stained with Texas Red-conjugated phalloidin after $2 \mathrm{~h}$ PDGF-B treatment. Arrows highlight the areas of cortical actin ruffling in $M T 1-M M P^{+/+}$VSMCs. $(D)$ Phosphorylated forms of AKT (pAKT) and ERK (pERK) were detected from the whole cell lysates of wild-type and MT1-MMP ${ }^{-/-}$VSMCs (25 $\mu \mathrm{g} /$ lane) treated with PDGF-B (10 ng/mL), FGF-2 (10 ng/mL), or 10\% FBS for $30 \mathrm{~min}$. $\alpha$-Tubulin served as a protein loading control. $(E)$ Aortic medial explants from wild-type or MT1- $M M P^{-1-}$ mice were stimulated with PDGF-B (10 ng/mL) for $30 \mathrm{~min}$. Protein extracts (50 $\left.\mu \mathrm{g} / \mathrm{lane}\right) \mathrm{were}$ subjected to Western blotting with antibodies directed against $\alpha$-tubulin or the phosphorylated forms of AKT and ERK. (F) Wild-type and MT1-MMP $P^{-/-}$VSMCs were growth-arrested in the absence or presence of synthetic MMP inhibitor BB-94 (5 $\left.\mu \mathrm{M}\right)$ for $48 \mathrm{~h}$ as indicated (similar results were obtained by $24 \mathrm{~h}$ incubation; data not shown). Cells were then treated with PDGF-B (10 ng/mL) with or without BB-94 for $30 \mathrm{~min}$ as indicated. Phosphorylated forms of AKT and ERK were monitored in cell lysates.

TGF- $\beta$ that have been associated with proliferative responses) (Egeblad and Werb 2002; Mu et al. 2002; data not shown).

The inability of cultured MT1-MMP $P^{-/-}$VSMCs to respond to PDGF-B in vitro raises the possibility that a similar defect exists in VSMC function in situ. However, attempts to extrapolate in vitro results into the in situ setting are complicated by the fact that isolated VSMCs are no longer embedded in the 3-D extracellular matrix that comprises the arterial wall. Further, isolated VSMCs rapidly dedifferentiate following in vitro culture and exhibit phenotypic characteristics distinct from those observed in vivo (Owens et al. 2004). Hence, to determine the status of the PDGF signaling cascade in situ, media explants were isolated from wild-type and $M T 1-M M P^{-/-}$mice and stimulated with PDGF-B for 30 min ex vivo. Importantly, similar to the results obtained with isolated VSMCs cultured under 2-D conditions, the $M T 1-M M P$-null VSMC explants failed to respond to PDGF-B as assessed by either ERK1/2 or Akt phosphorylation (Fig. 2E). While these results do not rule out the possibility that MT1-MMP deficiency alters the in vivo differentiation of VSMCs, and hence their responsiveness to PDGF-B (Dandre and Owens 2004; Owens et al. 2004), wild-type VSMCs cultured in vitro for $24 \mathrm{~h}$ with either the MMP inhibitor, BB-94 (Fig. 2F), or TIMP-2 (data not shown) displayed similar defects in PDGF-Binduced ERK1/2 and Akt activation.

\section{An MT1-MMP-PDGFR $\beta$ axis regulates PDGF-B responsiveness}

Given the muted ability of MT1-MMP-deficient VSMCs to respond to PDGF-B, efforts were next initiated to determine whether transducing $M T 1-M M P^{-/-}$cells with an MT1-MMP encoding retrovirus would selectively alter signaling or proliferation following PDGF-B versus FGF-2 stimulation. As shown in Figure 3, both PDGF-Bstimulated ERK signaling and proliferation responses were fully reconstituted following the introduction of full-length MT1-MMP into MT1-MMP $P^{-/-}$VSMCs. In contrast, FGF-2-dependent responses in ERK1/2 activation or proliferation remained unaffected following MT1-MMP expression (Fig. 3A,B). While the 20-amino- 
A

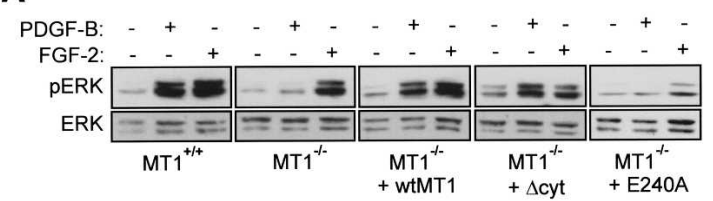

B

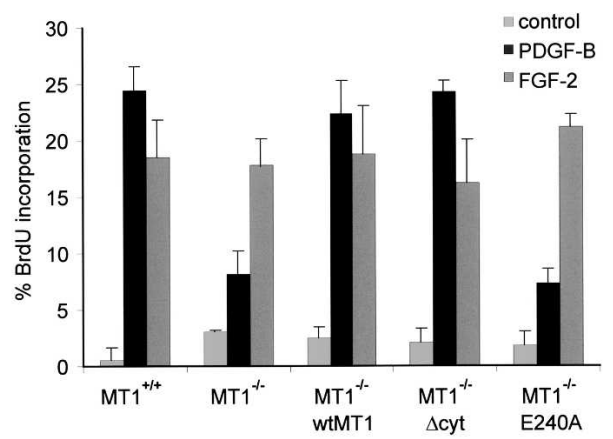

C

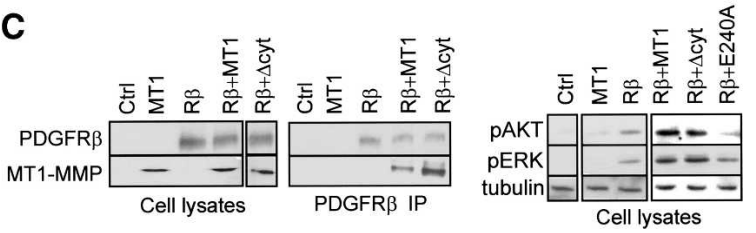

Figure 3. Regulation of PDGF-B/PDGFR $\beta$ signaling by MT1MMP. (A) MT1-MMP ${ }^{-/-}$VSMCs were infected with retroviruses encoding GFP (control vector), full length MT1-MMP (wtMT1), cytoplasmic tail-deleted MT1-MMP $(\Delta$ cyt), or catalytically inactive MT1-MMP (E240A) as indicated. Subconfluent growtharrested cultures of wild-type or retrovirus-infected MT1$M M P^{-/-}$VSMCs (cultured on type I collagen) were stimulated with PDGF-B or FGF-2 (both $10 \mathrm{ng} / \mathrm{mL}$ ) for $30 \mathrm{~min}$. Cell lysates (25 $\mu \mathrm{g} /$ lane) were analyzed for the phosphorylated forms of ERK (pERK) as well as total ERK. (B) BrdU incorporation by wild-type or retrovirus-infected $M T 1-M M P^{-/-}$VSMCs was assessed after a $24 \mathrm{~h}$ treatment with PDGF-B or FGF-2 (both $30 \mathrm{ng} / \mathrm{mL}$ ) as indicated. Results are expressed as mean $\pm 1 \mathrm{SD}(n=3)$. (C) COS-1 cells were transiently transfected with a control vector, or expression vectors encoding full-length (MT1), $\Delta$ cyt, or E240A forms of MT1-MMP, alone or in combination with PDGFR $\beta$ $(\mathrm{R} \beta)$. Transfected VSMCs were serum-starved for $18 \mathrm{~h}$, detached using $2 \mathrm{mM}$ EDTA, replated to $80 \%$ confluence atop type I collagen, and stimulated with PDGF-B $(10 \mathrm{ng} / \mathrm{mL})$ for $30 \mathrm{~min}$. Cell lysates were analyzed for the phosphorylated forms of AKT (pAKT) and ERK (pERK) with $\alpha$-tubulin serving as a loading control.

acid cytosolic tail of MT1-MMP has been posited to participate in ERK as well as Src tyrosine kinase signaling cascades (Gingras et al. 2001; Sounni et al. 2004), a taildeleted MT1-MMP mutant $(\Delta \mathrm{cyt})$ specifically rescued PDGF-B-dependent ERK activation and proliferation comparably to full-length MT1-MMP (Fig. 3A,B). In contrast, a catalytically inactive form of MT1-MMP (MTMMP E240A) that has been reported to trigger Rac activation (Cao et al. 2004) was unable to support PDGF-Binitiated signaling or proliferation (Fig. 3A,B).

The ability of MT1-MMP to reconstitute PDGF-B responsiveness in $M T 1-M M P^{-/-}$VSMCs without affecting
FGF-2-initiated effects suggests that MT1-MMP may function as a required participant in maximizing PDGFR $\beta$-dependent signaling. Consequently, the ability of PDGFR $\beta$ and MT1-MMP alone, or in combination, to affect PDGF signaling was examined in a host cell population (i.e., COS-1 cells that express undetectable levels of PDGFR $\beta$ or MT1-MMP). As expected, COS-1 cells transfected with either a control or MT1-MMP expression vector alone did not activate ERK1/2 or Akt in response to PDGF-B (Fig. 3C). Following transfection with PDGFR $\beta$ vector alone, limited ERK and Akt activation were registered in PDGF-B-stimulated cells (Fig. 3C). However, in MT1-MMP/PDGFR $\beta$ cotransfected cells, the physical association between the protease and receptor was reconstituted in tandem with a marked increase in ERK1/2 and Akt activation. Likewise, $\Delta$ cyt also formed a complex with PDGFR $\beta$ and supported PDGFB-dependent signaling, while MT1-MMP E240A was inactive (Fig. 3C) as was a transmembrane-deleted, soluble form of the enzyme (data not shown). Taken together, these results support a model wherein catalytically active MT1-MMP acts as an important accessory molecule in the PDGF-PDGFR $\beta$ signaling axis.

In vivo status of mural cell-endothelial cell interactions in $\mathrm{MT}^{-\mathrm{MMP}^{-/-}}$mice

The in vitro PDGF-B-selective defects observed in MT1$M M P^{-/-}$VSMC proliferation, chemotaxis, and downstream signaling recapitulate those reported in mesenchymal cells recovered from transgenic mice expressing PDGFR $\beta$ mutants incapable of recruiting key SH2-domain-binding proteins (Tallquist et al. 2003). Further, unlike PDGF-B-null or PDGFR $\beta$-null mice that die in utero or perinatally (Betsholtz 2003; Hoch and Soriano 2003), mice expressing signaling-defective PDGFR $\beta \mathrm{mu}-$ tant alleles survive into adulthood while exhibiting pronounced defects in pericyte development in the brain and eyes (Tallquist et al. 2000, 2003; Hoch and Soriano 2003). Hence, to determine whether MT1-MMP deficiency affects PDGF-PDGFR $\beta$-dependent vascular morphology, endothelial cell-mural cell interactions were first assessed in cerebral brain sections recovered from 4-

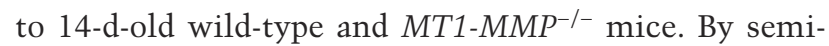
quantitative RT-PCR, no differences in PDGF-B mRNA levels were detected between wild-type and MT1$M M P^{-/-}$brain (data not shown). However, whereas average blood vessel length (as assessed by endothelial cellspecific CD31 staining) of matched areas in the cerebral cortex was not altered significantly in $M T 1-M M P^{-/-}$ mice $(1112 \pm 45 \mu \mathrm{m} /$ photographic area; mean $\pm 1 \mathrm{SD}$; $n=3$ ) as compared with wild-type littermate controls $(1041 \pm 32 \mu \mathrm{m} /$ photographic area; mean $\pm 1 \mathrm{SD} ; n=3)$, perivascular staining for the mural cell markers, desmin and $\alpha$-smooth muscle actin ( $\alpha$ SMA) were decreased markedly in MT1-MMP-null tissues (Fig. 4A). Western blot analyses of wild-type and MT1-MMP ${ }^{-/-}$brain extracts revealed comparable CD31 levels in the face of a $62 \pm 4 \%$ decrease in desmin levels (mean $\pm 1 S D ; n=4)$ 
Lehti et al.

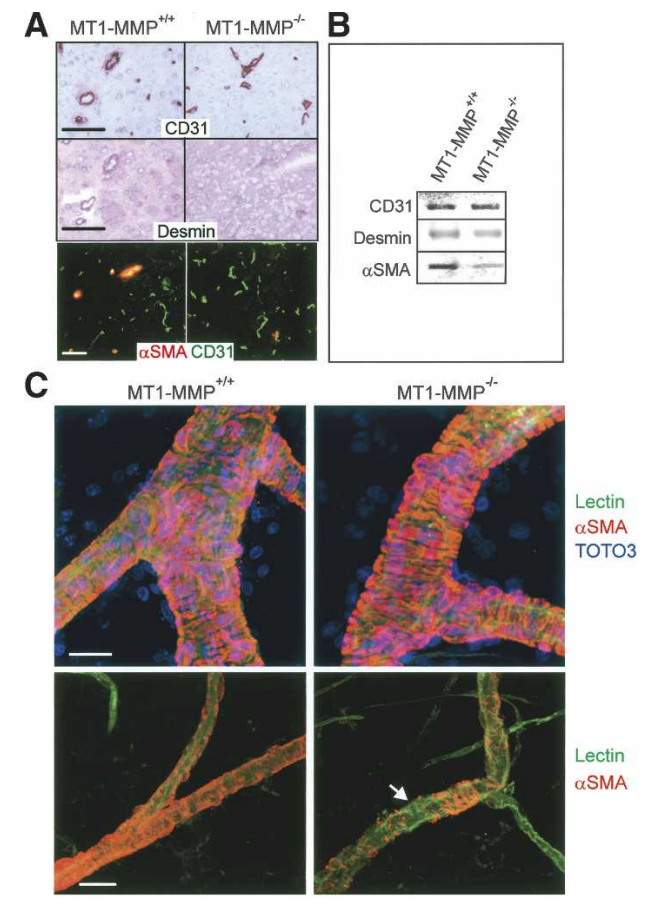

Figure 4. Defective mural cell investment of brain vessels in $M T 1-M M P^{-/-}$mice. (A) CD31, desmin, and $\alpha$ SMA immunohistochemistry of coronal cerebral sections from 14-d-old control littermate (left panel) or MT1-MMP-null (right panel) mice. CD31 stains endothelium, desmin stains mural cells in arteries, veins, and arterioles, as well as pericytes in capillaries and venules, $\alpha$ SMA stains VSMCs in arteries and arterioles. Bars, 50 $\mu \mathrm{m}$. (B) Western blotting of CD31, desmin, and $\alpha$ SMA from total brain extracts demonstrates reduced levels of desmin and $\alpha \mathrm{SMA}$ in $M T 1-M M P^{-/-}$brains relative to comparable CD31 levels in control littermate brains. $(C)$ Confocal laser scanning micrographs of arteries within the perineural vascular plexus (upper panels) and arterioles (lower panels) in brain sections visualized with triple fluorescence staining for VSMC ( $\alpha \mathrm{SMA}$; red), endothelium (lycopersicon esculentum lectin; green) and nuclei (TOTO-3; blue). Arrows highlight gaps in $\alpha$ SMA staining of $M T 1-M M P^{-/-}$arterioles that contrast with the extensive VSMC coverage of $M T 1-M M P^{+/+}$vessels. Bars, $20 \mu \mathrm{m}$.

and a $71 \pm 5 \%$ decrease in $\alpha$ SMA content (mean $\pm 1 S D$; $n=4$ ) (Fig. 4B).

In the brain, defects in PDGF/PDGFR $\beta$-dependent signaling alter mural cell recruitment in a site-specific manner. For example, while mural cells are abundant in the $P D G F-B^{-/-}$perineural vascular plexus, an almost complete loss of VSMC/pericytes occurs within the brain parenchyma (Hellström et al. 1999). In similar fashion, in $M T 1-M M P^{-/-}$brains, $\alpha$ SMA immunostaining coupled with confocal laser scanning microscopy demonstrates that large arteries within the perineural plexus of $M T 1-M M P^{-/-}$mice retained an intact mural cell coat (Fig. 4C). In contrast, in smaller intracerebral arteries, $M T 1-M M P^{-/-}$vessels contain areas that exhibit a marked decrease in the density of $\alpha$ SMA-positive mural cells (Fig. 4C). While small vessel-associated pericytes are frequently $\alpha$ SMA-negative in wild-type tissue, the capil- lary-associated mural cells can be readily detected by immunohistochemical analysis of desmin or NG2 expression (Morikawa et al. 2002). As shown in Figure 5A, intracerebral capillaries were decorated with desminand NG2-positive pericytes (areas of close contact between the red-stained, desmin- or NG2-positive pericytes and the green-stained endothelium appear yellow). Similarly, N-cadherin, an adhesion molecule coexpressed in endothelial cells and pericytes that mediates homotypic binding (Gerhardt and Betsholtz 2003; Paik et al. 2004), can be discerned readily (Fig. 5A). In MT1$M \mathrm{MP}^{-/-}$brains, however, the density of desmin- or NG2positive capillary pericytes was markedly decreased (Fig. $5 \mathrm{~A})$. Furthermore, despite the fact that neither PDGF-Bnor $P D G F R \beta$-null mice exhibit alterations in endothelial cell-pericyte apposition prior to death in utero /Gerhardt and Betsholtz 2003), a portion of the residual pericytes found in the $M T 1-M M P^{-/-}$brain not only display abnormal cell processes that project away from the endothelial cell surface, but also reduced junctional staining for $\mathrm{N}$ cadherin (Fig. 5A).

In PDGF- $B^{-/-}$or PDGFR $\beta^{-/-}$mice, the loss of the mural cell coat dramatically affects vessel wall architecture as well as endothelial cell structure (Lindahl et al. 1997; Hellström et al. 2001; Betsholtz 2003; Hoch and Soriano 2003). Defects range from irregular capillary diameter and structure, increased number of regressing capillary branches, microaneurysms, perivascular edema and reactive gliosis (Hellström et al. 2001; Betsholtz 2003; Hoch and Soriano 2003). Similarly, imaging of capillary endothelium of $M T 1-M M P^{-/-}$brains revealed a network of irregular-sized vessels with both regressing and dilated capillary structures in abundance (Fig. 5B). At the ultrastructural level, transmission electron micrographs of brain or retinal capillaries of littermate control mice highlight the architecture of the normal vasculature with regular lumens and tightly associated pericytes (Fig. $5 \mathrm{C})$. Profiles of pericyte nuclei or pericyte cellular processes were found in association with $55 \%$ and $45 \%$, respectively, of the wild-type capillaries in electron micrographs. In marked contrast, the density of pericyte nuclei or pericyte processes found in association with $M T 1-M M P^{-/-}$brain capillaries was reduced to approximately $12 \%$ and $23 \%$, respectively. Interestingly, in a fashion similar to that observed in PDGF- $B^{-/-}$capillaries (Hellström et al. 2001; Bjarnegård et al. 2004), atypical luminal folds of endothelium were frequently observed in the vasculature of the $M T 1-M M P^{-/-}$mice (Fig. 5C), as were signs of perivascular edema and reactive gliosis in the brain (i.e., increased desmin/NG2 staining in astroglial-like cells) (Fig. 5A, insets; Buniatian et al. 1999; Chen et al. 2002). Further, in the residual population of $M T 1-M M P^{-/-}$pericytes that could be identified, the mural cells were only loosely associated with the endothelium (Fig. 5C). Taken together, the vascular phenotype of $M T 1-M M P^{-/-}$mice is consistent with perturbed PDGF/ PDGFR $\beta$-dependent signaling in vivo and appears to phenocopy a PDGFR $\beta$ mutant-like hypomorphic state (Enge et al. 2002; Hoch and Soriano 2003; Lindblom et al. 2003). 
A

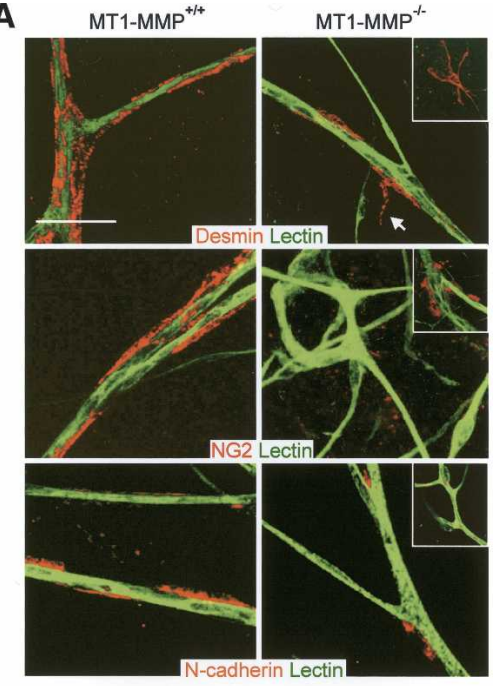

B

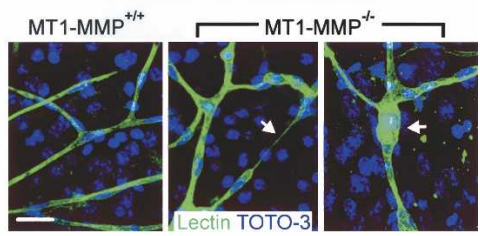

C MT1-MMP ${ }^{+t+}$
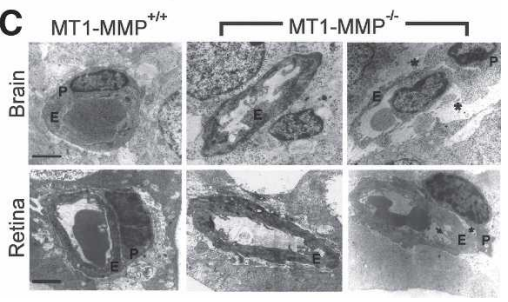

Figure 5. Abnormal pericyte density and morphology in MT1$M M P^{-/-}$brain microvessels. (A) Immunofluorescent double staining for endothelium (lycopersicon esculentum lectin; green) and mural cells using antibodies against desmin (upper panel, red) or NG2 (middle panel, red) illustrate reduced appearance of pericytes and abnormal pericyte extensions in MT1$M M P^{-/-}$brains (arrow in right panel). Insets show increased desmin and NG2 staining in nonvessel wall associated astrogliallike cells in $M T 1-M M P^{-/-}$brains. $\mathrm{N}$-cadherin staining (lower panel, red) highlights pericyte-endothelial cell junctions in control capillaries (left), whereas cytoplasmic staining predominates in $M T 1-M M P^{-/-}$pericytes (right). Inset shows punctuate $\mathrm{N}$-cadherin staining in discrete areas of endothelium in MT1$M M P^{-/-}$brains. Bar, $10 \mu \mathrm{m}$. (B) Confocal laser scanning micrographs of cerebral brain sections from 14-d-old littermate control (left) and MT1-MMP-null (middle and right) mice following immunofluorescent double staining for endothelium (lectin; green) and nuclei (TOTO-3; blue). Arrows point to dilated and regressing capillaries in $M T 1-M M P$-null brains. Bar, $10 \mu \mathrm{m} .(C$, left panel) Transmission electron micrographs of capillary crosssections in 4-d-old control mouse brains and retinas display regular lumens and lining endothelial cells (E) surrounded by tightly apposed pericytes (P). In $M T 1-M M P^{-/-}$tissues, arrows indicate areas of irregular endothelial cell thickness and extensive luminal projections that either lack surrounding pericytes (middle panel) or are surrounded by abnormally associated pericyte-like cells (right panel). An asterisk marks the area of perivascular edema in MT1-MMP-null brains. Bar, $5 \mu \mathrm{m}$.
Ex vivo analysis of the post-natal MT1-MMP/PDGFR axis.

Despite the fact that $P D G F-B$ and $P D G F R \beta$ are widely expressed (e.g., endothelial cells and fibroblasts) (Betsholz 2003), mice null for either the growth factor ligand or receptor display developmental defects that are largely confined to the muscle lineage (Crosby et al. 1998; Hellström et al. 1999; Tallquist et al. 2003). Recently, however, analyses of the wound healing response in chimeric adult mice expressing both PDGFR $\beta^{+/+}$and PDGFR $\beta^{-/-}$ alleles have demonstrated that the PDGF-B/PDGFR $\beta$ axis exerts important effects on endothelial cells as well as fibroblast functions in the post-natal state /Crosby et al. 1999). Hence, to assess PDGF-B responsiveness in an ex vivo wound-like environment, tissue explants recovered from $M T 1-M M P^{+/+}$and $M T 1-M M P^{-/-}$mice were suspended in 3-D fibrin gels and stimulated with either an angiogenic mix of vascular endothelial growth factor (VEGF) and hepatocyte growth factor (HGF), or with PDGF-B alone. As murine cells can traverse 3-D constructs of fibrin, the chief component of the provisional matrix that surrounds wound sites, by an MT1-MMPindependent process (Hiraoka et al. 1998; Hotary et al. 2002; Chun et al. 2004), both wild-type and $M T 1-M M P^{-/-}$ explants mount a comparable "wound response" following the addition of VEGF/HGF (Fig. 6A). After a 6-d culture period, the surrounding fibrin gel is infiltrated with patent neovessels, fibroblasts, and mural cells, as described previously (Nicosia et al. 1994; Chun et al. 2004). However, whereas wild-type endothelial cells are surrounded by $\alpha$ SMA-positive mural cells, similar endothelial cell-mural cell interactions cannot be identified in $M T 1-M M P^{-/-}$cells despite comparable numbers of neovessels (Fig. 6A). More strikingly, whereas PDGF-B triggers a florid outgrowth of neovessels and $\alpha$ SMA-positive cells (Nicosia et al. 1994), the $M T 1-M M P^{-/-}$explants display an almost complete failure to respond to the growth factor (Fig. 6B). Hence, by recapitulating a wound-like, post-natal environment, $M T 1-M M P^{-/-}$tissue explants display a more global, PDGF-B-specific defect in mesenchymal cell behavior that mirrors the response of $P D G F R \beta^{-/-}$mural cells, endothelial cells, and fibroblasts in chimeric mice (Crosby et al. 1999).

\section{Discussion}

The PDGF-B/PDGFR $\beta$ axis plays a dominant role in regulating mural cell recruitment and proliferation in vivo (Betsholz 2003; Hoch and Soriano 2003). During embryogenesis, PDGFR $\beta$-positive mural cell progenitors arise in a PDGF-B-independent fashion, and then proceed to expand and migrate along developing blood vessels in response to signaling by endothelial cell-derived PDGF-B (Hellström et al. 1999; Betsholtz 2003; Gerhardt and Betsholtz 2003). In the absence of intact PDGF/PDGFR $\beta$ signaling, mural cell expansion and recruitment along large arteries and small vessels are affected to varying degrees in a tissue-specific fashion that appears to reflect the local activation of compensatory, but less effective, signaling cascades (Hellström et al. 1999; Betsholtz 2003; 


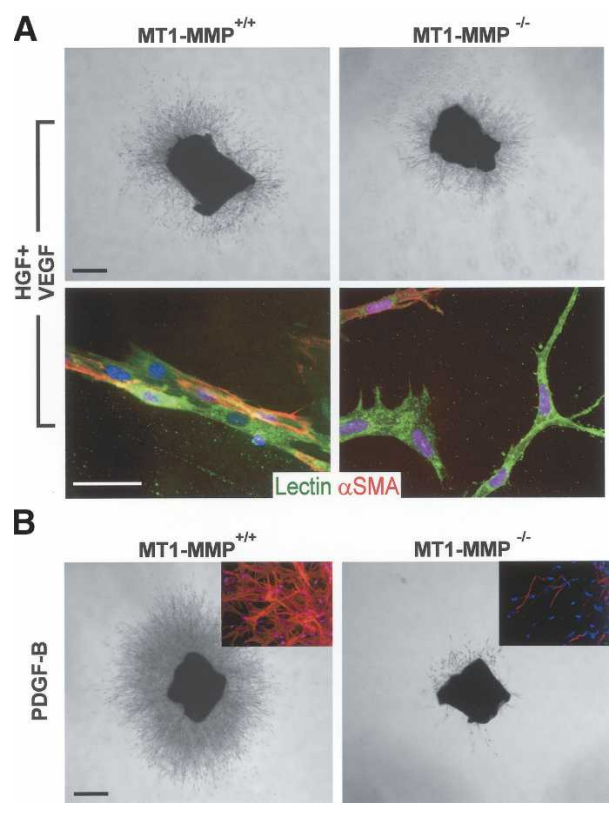

Figure 6. MT1-MMP directs PDGF-dependent cell outgrowth ex vivo. (A) Control littermate (left panel) and $M T 1-M M P^{-/-}$ (right panel) tissue fragments were suspended in fibrin gels 13 $\mathrm{mg} / \mathrm{mL}$ ) and stimulated with VEGF and HGF (50 ng/mL each) in $0.5 \%$ plasma-derived serum. (Upper panels) Phase-contrast microscopy reveals comparable (cell/neovessel) outgrowth from control and MT1-MMP-null tissues after a 6-d culture period (bar, $500 \mu \mathrm{m})$. (Lower panels) Confocal laser scanning micrographs of whole mount preparations show endothelial structures (lycopersicon esculentum lectin; green) surrounded by $\alpha$ SMA-positive cells (red) in control cultures (bar, $10 \mu \mathrm{m})$. MT1$M M P^{-/-}$cell outgrowths are mainly comprised of lectin-positive cells and neovessels with occasional $\alpha$ SMA-positive cells. Nuclei are visualized with TOTO-3 (blue). ( $B$, left) In response to PDGF-B $(25 \mathrm{ng} / \mathrm{mL})$, tissue fragments from wild-type littermate controls mount a robust cell outgrowth as assessed by phasecontrast microscopy of the transparent gels that is largely comprised of $\alpha$ SMA-positive mural cells and fibroblasts (inset). (Right) In contrast, explants isolated from MT1-MMP-null mice display defective outgrowth and almost no $\alpha$ SMA-positive cells (inset). Nuclei are stained blue with TOTO-3. Bar, $500 \mu \mathrm{m}$.

Gerhardt and Betsholtz 2003; Tallquist et al. 2003). Indeed, in chimeric mice expressing both wild-type and $P D G F R \beta^{-/-}$mural cells, $P D G F R \beta^{+/+}$cells display a marked competitive advantage over null cells such that $P D G F R \beta^{-1-}$ pericytes and VSMCs are almost completely excluded from the developing vascular tree-from the aorta through to capillary beds (Crosby et al. 1998; Hellström et al. 1999; Tallquist et al. 2003). While mutations in other signaling processes can impact VSMC/pericyte function (e.g., the angiopoietin-1/tie-2 axis, endoglin, the activin-like kinase, Alk-1, SMAD5, the transcription factor, LKLF, or the G-coupled receptor, Edg-1), most of these effects appear to arise as a consequence of primary defects in the endothelium, with secondary effects exerted on the mural cell coat (for review, see Gerhardt and Betsholtz 2003). Hence, confronted with (1) a preliminary observation that the aorta of young MT1-MMP-/mice appear hypoplastic despite a normal endothelium, and (2) that MT1-MMP is highly expressed in a mural cell-specific fashion during arteriogenesis (Apte et al. 1997), we posited that the membrane-anchored metalloproteinase might play a role in the PDGF-B/PDGFR $\beta$ signaling cascade.

MT1-MMP is one of six type I transmembrane or GPIanchored proteases found in the MMP family (Egeblad and Werb 2002; Seiki et al. 2003). Synthesized as a proenzyme, the proteinase undergoes intracellular activation within the trans-Golgi network wherein the N-terminal proprotein domain is proteolytically removed by one or more members of the proprotein convertase family (Yana and Weiss 2000). Catalytically active MT1MMP then traffics to the cell surface where it hydrolyzes target substrates in either a cis or trans fashion (Egeblad and Werb 2002; Seiki et al. 2003). By cleaving extracellular matrix components (e.g., type I collagen) or surfaceassociated molecules (e.g., CD44, $\alpha_{v} \beta_{3}$, transglutaminase), MT1-MMP has been proposed to play a dominant role in regulating $2-\mathrm{D}$ or $3-\mathrm{D}$ cell migration, albeit in a stimulus-independent manner (Hotary et al. 2000; Seiki et al. 2003; Takino et al. 2004). In this fashion, MT1MMP is usually positioned as a downstream or even final mediator of growth factor-initiated signal transduction cascades. In contrast, the findings presented in this paper demonstrate that mural cells unexpectedly use MT1MMP as a necessary cofactor in specifically propagating signaling through the PDGF-B/PDGFR $\beta$ axis.

In vitro, PDGF-B regulates mural cell migration and proliferation via a multistep process linked to PDGFR $\beta$ expression levels, kinase activity, and downstream signaling (Betsholtz 2003; Hoch and Soriano 2003; Tallquist et al. 2003). Given a selective defect in the ability of $M T 1-M M P^{-/-}$VSMCs to respond to PDGF-B relative to PDGF-A, PDGF-AB, FGF-2, IGF, or serum, coupled with the apparently normal levels of PDGFR $\beta$ at the cell surface and intact PDGFR $\beta$ kinase activity, our attention focused on downstream signaling events. While activated PDGFR $\beta$ is known to recruit at least 10 SH2-domain-binding proteins (including Src family kinase, PI3K, RasGAP, PLC $\gamma$, and Shc), studies to date have not identified a dominant pathway that regulates mural cell proliferation or development (Hoch and Soriano 2003). Instead, current models support a process wherein PDGFR $\beta$ activates redundant pathways such that the role of individual signaling cascades is less important than their additive effect on the strength of the transmitted signal (Fambrough et al. 1999; Tallquist et al. 2003). As such, ERK $1 / 2$ and Akt activation are commonly used as convenient surrogate markers of the integrity of PDGFR $\beta$ signaling as these effector pathways play important roles in regulating VSMC function (Hoch and Soriano 2003; Tallquist et al. 2003). Indeed, MT1$M M P$ deficiency strongly interfered with PDGFR $\beta$-dependent ERK1/2 and Akt phosphorylation without impacting on the ability of these effector pathways to respond to alternate receptor-ligand interactions. More importantly, PDGF-B-selective defects in PDGFR $\beta$ downstream signaling were reversed completely when $M T 1-M M P^{-/-}$VSMCs were transduced with the wild- 
type proteinase. Interestingly, despite the fact that MT1MMP has been reported to transduce signals capable of activating ERK1/2 or Src-tyrosine kinase via undefined processes requiring the MT1-MMP cytosolic tail (Gingras et al. 2001; Sounni et al. 2004), a tail-deleted but transmembrane-anchored construct rescued PDGF-B-dependent ERK1/2 phosphorylation and proliferation comparably to the full-length proteinase. Further, while MT1-MMP proteolytic activity, endocytosis, surface localization, and association with caveolin-1 have each been proposed to require the presence of the proteinase's intact cytosolic tail (Lehti et al. 2000; Jiang et al. 2001; Galvez et al. 2002, 2004; Labrecque et al. 2004), none of these interactions can be considered critical to PDGFR $\beta$ signaling. Similarly, whereas catalytically inactive MT1MMP has been reported to stimulate the chemokinetic activity of transfected cells via a rac-dependent mechanism (Cao et al. 2004), only catalytically active MT1$\mathrm{MMP}$ restored PDGF-B responsiveness in $M T 1-M M P$ null VSMCs.

While our studies demonstrate that MT1-MMP synergistically augments PDGFR $\beta$ signaling in $M T 1-M M P$-deficient VSMCs, a cofactor function for the proteinase is not restricted to cell types of smooth muscle cell origin as effects on downstream signaling cascades could be recapitulated in $M T 1-M M P$ - and PDGFR $\beta$-cotransfected COS-1 cells. Nonetheless, the mechanistic processes underlying MT1-MMP/PDGFR $\beta$ interactions require further study and may involve as yet undefined accessory molecules. Interestingly, PDGFR $\beta$ is known to functionally interact with at least two potential MT1-MMP targets at the VSMC surface, $\alpha_{v} \beta_{3}$ (Ratnikov et al. 2002) and low density lipoprotein receptor-related protein (LRP; Rozanov et al. 2004). Recent studies have demonstrated that PDGFR $\beta$ activity can be modulated through its interactions with the $\alpha_{v} \beta_{3}$ integrin (Schneller et al. 1997). However, despite the fact that MT1-MMP can cleave $\alpha_{v} \beta_{3}$ and modify integrin function (Ratnikov et al. 2002), our preliminary studies indicate that $\beta_{3}$-null VSMCs activate ERK1/2 comparably to wild-type cells following stimulation with PDGF-B (L. Lehti and S.J. Weiss, unpubl.). Similarly, LRP has recently been reported to function as a negative regulator of PDGFR $\beta$ activity (Boucher et al. 2003) and is likewise susceptible to MT1-MMP hydrolysis (Rozanov et al. 2004). Nonetheless, LRP is also sensitive to proteolysis by MT3-MMP (Rozanov et al. 2004), and in unpublished work (K. Lehti, T.H. Chun, and S.J. Weiss, unpubl.), we find that PDGFR $\beta$ signaling defects in $M T 1-M M P^{-/-}$VSMCs are not rescued following transduction with active MT3-MMP. Given the fact that MT1-MMP cannot participate in PDGFR $\beta$ signaling when expressed as a transmembrane-deleted soluble enzyme or function in a trans fashion when MT1-MMPexpressing COS- 1 cells are mixed with PDGFR $\beta$-expressing cells (data not shown), we favor a model wherein MT1-MMP hydrolyzes either the receptor itself or a near neighbor, accessory molecule(s). In either case, however, optimal signaling not only requires an intact PDGF-B/ PDGFR $\beta$ couplet, but also membrane-tethered, catalytically active MT1-MMP.
Studies of either PDGF-B- or PDGFR $\beta$-null mice demonstrate clearly that mural cell recruitment to the developing vasculature is impaired severely in the absence of either the ligand or its cognate receptor (Leveen et al. 1994; Soriano 1994; Lindahl et al. 1997; Hellström et al. 1999). Further, in the absence of an intact mural cell coat, vessel wall structure and function are perturbed significantly (Lindahl et al. 1997; Hellström et al. 2001; Betsholtz 2003; Hoch and Soriano 2003). Given that PDGF-B/PDGFR $\beta$ interactions are not completely eliminated in the face of $M T 1-M M P$ deficiency, what predictions might have been made with regard to the phenotypic consequences of this hypomorphic state? Interestingly, an allelic series of PDGFR $\beta$ mutants have been generated by inserting Tyr-Phe substitutions into the receptor's autophosphorylation sites, which serve to ablate interactions with key $\mathrm{SH} 2$-domain-binding proteins (Tallquist et al. 2003). In the most aggressively engineered construct, the mutated receptor (termed F7) is unable to recruit Src, Grb2, PI3K, RasGAP, SHP-2, or PLC $\gamma$ (Tallquist et al. 2003). Despite these changes, mutant PDGFR $\beta$ retains the ability to trigger an attenuated activation of ERK1/2 and Akt, which approximates the responses we observed in $M T 1-M M P$-null VSMCs. In contrast to $P D G F R \beta$-null mice, the $\mathrm{F} 7$ mutants survive into adulthood and display a significant loss in pericyte density that is confined largely to the brain and eyes (Tallquist et al. 2000, 2003). Similarly, in MT1-MMPnull mice, we demonstrate that mural cell density in these target organs is decreased significantly. Further, remaining mural cell-endothelial cell interactions were frequently disrupted, leading to a series of vessel wall defects that phenocopy those observed in PDGF- $B$ or PDGFR $\beta$ mutant mice (Betsholtz 2003; Hoch and Soriano 2003). However, unlike $P D G F-B^{-/-}$or $P D G F R \beta^{-/-}$ mice (Gerhardt and Betsholz 2003), we find that MT1$M M P^{-/-}$pericytes frequently fail to tightly appose themselves with the surrounding vasculature. While this phenotype raises the possibility that other defects arise in pericytes or endothelial cells as a consequence of an effect of MT1-MMP deficiency on other signaling pathways (e.g., ang-1/tie-2, sphingosine 1-phosphate/EDG-1, endoglin) (for review, see Jain 2003), the full gamut of ramifications imposed by the attenuated PDGF-B response observed in these cells requires additional study. Likewise, we note that $M T 1-M M P^{-/-}$mice display a runted status as they develop post-natally as well as a shortened life span (Holmbeck et al. 1999; Oblander et al. 2005). Nonetheless, $M T 1-M M P^{-/-}$mice are indistinguishable from wild-type littermates until after post-natal day 5, a time point that postcedes the major changes we detected in the structure of the aortic wall. Indeed, while the increased morbidity and mortality displayed by $M T 1-M M P^{-/-}$mice may hint at additional, and as yet uncharacterized, defects in null tissues, other organ systems including the pulmonary tree, salivary glands, and kidney exhibit only subtle alterations in structure (Koshikawa et al. 2004; Oblander et al. 2005). Finally, the ability of MT1-MMP to regulate the tissue-invasive activity of fibroblasts and endothelial cells in collagen-rich 
tissues (Chun et al. 2004; Sabeh et al. 2004) raises the possibility that some portion of the vascular defects might be independently ascribed to the matrix remodeling potential of the enzyme. However, as noted recently, the collagen content of neonatal tissues is low (Caulfield and Borg 1979; Mays et al. 1988), and little, if any, interstitial collagen can be found in the adult brain (Goldbrunner et al. 1998). These issues notwithstanding, defects in PDGF-B-initiated signaling were clearly noted in a fibrin-rich environment that is readily traversed by MT1- $M M P^{-/-}$cells (Hotary et al. 2002; Chun et al. 2004). Hence, we propose that MT1-MMP can regulate VSMC/ pericyte function in a fashion most consistent with its accessory role in PDGFR $\beta$ signaling.

Historically, interest in the role of PDGF-B/PDGFR $\beta$ signaling during mural cell investment of the vasculature has been primarily confined to the developing organism (Betsholtz 2003; Hoch and Soriano 2003). More recently, however, PDGF-B signaling through PDGFR $\beta$ has been shown to play a critical role in not only stabilizing the vasculature of growing tumors, but also in regulating the function of the angiogenic vessels and stromal cell populations (Abramsson et al. 2003; Bergers et al. 2003; Saharinen and Alitalo 2003; Dong et al. 2004). As neoplastic events largely recapitulate wound healinglike programs (Dvorak 1986), we posit that the novel MT1-MMP/PDGFR $\beta$ axis described here may well impact on neovessel development, function, and stabilization not only during development, but during pathologic states as well.

\section{Materials and methods}

\section{Cell isolation and culture}

Mouse vascular smooth muscle cells were isolated from 10-16d-old mice with targeted deletions in either MT1-MMP or MMP2 genes (Itoh et al. 1997; Holmbeck et al. 1999) as well as from wild-type littermates (Stegemann and Nerem 2003). Briefly, the thoracic aortae were dissected into fragments, endothelial cells removed by gentle scraping, and the media explants stripped of adventitia. Tissues were partially digested with collagenase type $2(1.5 \mathrm{mg} / \mathrm{mL}$; Worthington) and plated in DMEM (GIBCO) supplemented with $10 \%$ fetal bovine serum (FBS; Hyclone), $100 \mathrm{U} / \mathrm{mL}$ penicillin, $100 \mu \mathrm{g} / \mathrm{mL}$ streptomycin, $0.25 \mu \mathrm{g} / \mathrm{mL}$ fungizone, and $2 \mathrm{mM}$ L-glutamine to allow the migration of VSMCs from the partially dissociated explants. Isolated VSMCs as well as COS-1 cell line (ATCC) were maintained in complete DMEM medium. VSMCs were used between passages 1 and 6 .

\section{Transient transfections and viral expression of exogenous MT1-MMP proteins}

Subcloning of HA-tagged human MT1-MMP cDNA, as well as cDNAs encoding mutant MT1-MMP with a cytosolic tail-deletion $\left(\mathrm{M}^{1}-\mathrm{R}^{563} ; \Delta \mathrm{cyt}\right)$ or inactivating $\mathrm{E}^{240}$ to A substitution in the active site (E240A), into retroviral vector has been described (Chun et al. 2004). Retroviral supernatants were produced using Phoenix-E host cells, and the subconfluent monolayers of the isolated VSMCs cultured in the retroviral supernatant for $12 \mathrm{~h}$. The infection efficiency was monitored by EGFP expression in cells infected with control retrovirus coding for EGFP. VSMCs infected with $>95 \%$ efficiency were used for signaling and BrdU experiments after $48 \mathrm{~h}$.

COS-1 cells were transiently transfected with a control vector (pCR3.1; Invitrogen), or expression vectors encoding full length, $\Delta$ cyt, and E240A forms of MT1-MMP, as well as human PDGFR $\beta$ (provided by A. Kazlauskas, Harvard Medical School, Boston, MA) using FuGENE 6 (Roche). For cotransfection experiments, $0.1 \mu \mathrm{g}$ of $M T 1-M M P$ plasmid and $1 \mu \mathrm{g}$ of $P D G F R \beta$ plasmid were used.

In vitro immunofluorescence, BrdU incorporation, and TUNEL assays

Isolated VSMCs were fixed with $3 \%$ paraformaldehyde, permeabilized with $0.1 \%$ Triton X-100, and $\alpha$ SMA or MT1-MMP expression assessed by immunostaining with Cy3 conjugated $\alpha$ SMA mAb (clone 1A4; Sigma) or affinity-purified polyclonal anti-MT1-MMP antibodies combined with Alexa Fluor 488 goat anti-rabbit IgG (Molecular Probes). Texas Red-conjugated phalloidin (Molecular Probes) was used to visualize polymerized actin. Stained samples were mounted in hard-set Vectashield containing DAPI for nuclear staining (Vector Laboratories).

For BrdU incorporation, VSMCs were plated atop type I collagen gels (acid extracted from rat tail tendons; Hotary et al. 2000) in DMEM with $10 \%$ FBS for $48 \mathrm{~h}$. VSMCs were then washed with PBS, and serum-starved in DMEM with $0.1 \%$ BSA for $48 \mathrm{~h}$ followed by incubation with human recombinant PDGF-A, PDGF-B, TGF- $\beta$, FGF-2, IGF-1, EGF (30 ng/mL each, except for TGF- $\beta$ at $10 \mathrm{ng} / \mathrm{mL}$; all from R\&D Systems), 10\% FBS, or vehicle for $24 \mathrm{~h}$. Alternatively, serum-starved VSMCs were replated on wells coated with type I collagen, fibronectin (Sigma), vitronectin (Sigma), or Matrigel (Becton-Dickinson) (each $100 \mu \mathrm{g} / \mathrm{mL}$ ) at the density of $1 \times 10^{4}$ cells $/ \mathrm{cm}^{2}$ in DMEM with $0.1 \%$ BSA followed by incubation with growth factors as above. After $120 \mathrm{~min}$ pulse with $10 \mu \mathrm{M} \mathrm{BrdU}$, cells were fixed and BrdU incorporation determined using monoclonal antiBrdU antibodies (Roche). Apoptosis was assessed by TUNEL assay (Fluorescein Direct Apoptag; Intergen). The average ratios between BrdU- or TUNEL-positive and total DAPI-stained nuclei were counted from six randomly selected fields of triplicate wells. Results are representative of at least three experiments performed.

\section{Cell treatments, immunoblotting, and immunoprecipitation}

VSMCs or transfected COS-1 cells were cultured and serumstarved on type I collagen as described above followed by incubation with PDGF-B, FGF-2 (both $10 \mathrm{ng} / \mathrm{mL}$ ), 10\% FBS, or vehicle for 0-120 min as indicated in the text. The cells were then washed and lysed in $50 \mathrm{mM}$ Tris-HCl buffer ( $\mathrm{pH}$ 8.0) containing $150 \mathrm{mM} \mathrm{NaCl}, 1 \%$ Triton X-100, $10 \mathrm{mM}$ EDTA, proteinase inhibitor cocktail set III (Calbiochem), $100 \mathrm{mM} \mathrm{Na} \mathrm{VO}_{2}$, and $100 \mathrm{mM}$ NaF. In selected experiments, VSMCs were pretreated with the synthetic MMP inhibitor, BB-94 (5 $\mu \mathrm{M}$ final concentration in $0.1 \%$ DMSO; British Biotechnology) in the serumstarvation medium for $24-48 \mathrm{~h}$ prior to, and during, growth factor stimulation. Cell surface biotinylation with $0.5 \mathrm{mg} / \mathrm{mL}$ Sulfo-NHS-biotin (Pierce) for the detection of cell surface PDGFR $\beta$ was carried out as described (Lehti et al. 1998). For the ex vivo signaling analysis, aortic media explants were isolated in serum-free DMEM and subjected to stimulation with PDGF-B $(20 \mathrm{ng} / \mathrm{mL})$ for $30 \mathrm{~min}$. Protein extracts from media explants were prepared by sonication in RIPA lysis buffer. Protein concentrations of the clarified cell and tissue extracts were determined by BCA-protein assay kit (Pierce), and equal amounts of protein subjected to SDS-PAGE, or immunoprecipi- 
tation with rabbit polyclonal antibodies to PDGFR (SantaCruz) as described (Lehti et al. 1998). Western blotting was carried out with primary antibodies against $\alpha$-tubulin, phosphotyrosine (both from Santa-Cruz), PDGFR $\beta$ (rabbit polyclonal from Santa-Cruz and goat polyclonal from RD Systems), MT1MMP (Ab-3) (Lehti et al. 2000), phospho-Akt (S473), phosphoERK1/2 (T202/Y204), and ERK1/2 (all three from Cell Signaling Technology). Quantification of scanned images was carried out using Image Quant 5.2 software. Results are representative of at least two experiments performed.

\section{Histology}

Aorta or brain tissues of 4- to 14-d-old littermate control, MT1$\mathrm{MMP}^{-/-}$or $\mathrm{MMP2}^{-/-}$mice were fixed with $4 \%$ paraformaldehyde. Paraffin-embedded tissues were sectioned $(5 \mu \mathrm{m})$ and stained with hematoxylin and eosin. For immunohistochemistry, coronal cerebral frozen sections were post-fixed with acetone/methanol (1:1) and immunostained with rat monoclonal anti-CD31 (PECAM-1, BD Biosciences), rabbit polyclonal antibodies against desmin (DAKO), and Cy3-conjugated mouse monoclonal anti- $\alpha$ SMA. For transmission electron microscopy, tissues were fixed with $2 \%$ glutaraldehyde and $1.5 \%$ paraformaldehyde, and processed as described (Hotary et al. 2000).

Immunohistological analyses of 200 - $\mu$ m thick coronal cerebral sections (prepared with Leica VT 1000S Vibratome from tissues embedded in $10 \%$ agarose) were performed essentially as described (Morikawa et al. 2002). Briefly, sections were incubated in PBS containing 5\% normal goat serum (Jackson ImmunoResearch, ), $0.5 \%$ Triton X-100 (Sigma), 0.5\% bovine serum albumin (BSA; Sigma) for $1 \mathrm{~h}$ at room temperature followed by incubation with primary antibodies for $16 \mathrm{~h}$ at $4^{\circ} \mathrm{C}$. Endothelium was stained with fluorecein-conjugated lycopersicon esculentum lectin (Vector Laboratories) and mural cells with Cy3conjugated mouse monoclonal anti- $\alpha$ SMA, rabbit polyclonal anti-desmin, or rabbit polyclonal anti-NG2 (Chemicon) antibodies. Mouse monoclonal anti-N-cadherin antibody (SantaCruz) was used to visualize endothelial-pericyte binding interactions. After washing (0.2\% Triton X-100 in PBS), sections were incubated with Alexa Fluor 594 goat anti-mouse or antirabbit IgGs for $6 \mathrm{~h}$ at room temperature. Nuclei were stained with TOTO-3 iodide (642/660; Molecular Probes). Following mounting in Vectashield (Vector Laboratories), specimens were examined with a Leica DM IRB microscope or a Perkin-Elmer Ultraview RS laser-scanning confocal microscope. Confocal images were stored as digital files with Ultraview RS software, and viewed with Photoshop (Adobe).

\section{Chemotaxis assay}

Chemotaxis assays were performed using Falcon cell culture inserts with 8 - $\mu \mathrm{m}$ pore membranes coated with type I collagen $(10 \mu \mathrm{g} / \mathrm{mL})$ in 24 -well cell culture plates. VSMCs $\left(5 \times 10^{4}\right)$ were plated in the upper chambers of the inserts in DMEM, and PDGF-B or FGF-2 (both $10 \mathrm{ng} / \mathrm{mL}$ ) added to the lower compartment of the chambers. After a $6 \mathrm{~h}$ incubation, the cells were fixed and stained (40\% methanol, $10 \%$ acetic acid, and $0.1 \%$ Coomassie Blue) and washed with the same fixative, but without the dye. The cells from the upper surface were removed with a cotton swab and the number of migrated cells counted in three randomly selected fields of triplicate wells.

\section{Ex vivo angiogenesis assay}

Mouse aortic ring assays were performed with minor modifications of protocols described previously (Nicosia et al. 1994;
Chun et al. 2004). Isolated aortae were sectioned (1 mm square fragments) and embedded in $3.0 \mathrm{mg} / \mathrm{mL}$ cross-linked fibrin (Hotary et al. 2000) and cultured in RPMI (GIBCO) supplemented with $0.5 \%$ plasma-derived serum (Sigma) and $100 \mu \mathrm{g} / \mathrm{mL}$ aprotinin in the presence of either $50 \mathrm{ng} / \mathrm{mL}$ recombinant human VEGF-165 and recombinant human HGF $(50 \mathrm{ng} / \mathrm{mL}$, both provided courtesy of Genentech), or $25 \mathrm{ng} / \mathrm{mL}$ human recombinant PDGF-B. Cell and neovessel outgrowth was examined with a Leica DM IRB microscope and images captured with SPOT camera and software. After $6 \mathrm{~d}$, the fibrin-embedded explants were fixed with $1 \%$ paraformaldehyde and whole mounts stained with lectin, anti- $\alpha$ SMA, and TOTO-3.

\section{Acknowledgments}

This work was supported by the National Institutes of Health (R01 CA71699; S.J.W.). K.L. received support from the Finnish Cultural Foundation and The Academy of Finland.

\section{References}

Abramsson, A., Lindblom, P., and Betsholtz, C. 2003. Endothelial and nonendothelial sources of PDGF-B regulate pericyte recruitment and influence vascular pattern formation in tumors. J. Clin. Invest. 112: 1142-1152.

Apte, S.S., Fukai, N., Beier, D.R., and Olsen, B.R. 1997. The matrix metalloproteinase-14 (MMP-14) gene is structurally distinct from other MMP genes and is co-expressed with the TIMP-2 gene during mouse embryogenesis. J. Biol. Chem. 272: 25511-25517.

Bergers, G., Song, S., Meyer-Morse, N., Bergsland, E., and Hanahan, D. 2003. Benefits of targeting both pericytes and endothelial cells in the tumor vasculature with kinase inhibitors. J. Clin. Invest. 111: 1287-1295.

Betsholtz, C. 2003. Biology of platelet-derived growth factors in development. Birth Defects Res. 69: 272-285.

Bjarnegård, M., Enge, M., Norlin, J., Gustafsdottir, S., Fredriksson, S., Abramsson, A., Takemoto, M., Gustafsson, E., Fassler, R., and Betsholtz, C. 2004. Endothelium-specific ablation of PDGFB leads to pericyte loss and glomerular, cardiac and placental abnormalities. Development 131: 18471857.

Boucher, P., Gotthardt, M., Li, W.-P., Anderson, R.G.W., and Herz, J. 2003. LRP: Role in vascular wall integrity and protection from atherosclerosis. Science 300: 329-332.

Buniatian, G.H., Gebhardt, R., Mecke, D., Traub, P., and Wiesinger, H. 1999. Common myofibroblastic features of newborn rat astrocytes and cirrhotic rat liver stellate cells in early cultures and in vivo. Neurochem. Int. 35: 317-327.

Cao, J., Kozarekar, P., Pavlaki, M., Chiarelli, C., Bahou, W.F., and Zucker, S. 2004. Distinct roles for the catalytic and hemopexin domains of membrane type 1-matrix metalloproteinase in substrate degradation and cell migration. J. Biol. Chem. 279: 14129-14139.

Caulfield, J.B. and T.K. Borg. 1979. The collagen network of the heart. Lab. Invest. 40: 364-372.

Chen, Z.J., Negra, M., Levine, A., Ughrin, Y., and Levine, J.M. 2002. Oligodendrocyte precursor cells: Reactive cells that inhibit axon growth and regeneration. I. Neurocytol. 31: 481-495.

Chun, T.H., Sabeh, F., Ota, I., Murphy, H., McDonagh, K.T., Holmbeck, K., Birkedal-Hansen, H., Allen, E.D., and Weiss, S.J. 2004. MT1-MMP-dependent neovessel formation within the confines of the three-dimensional extracellular matrix. J. 
Cell Biol. 167: 757-767.

Crosby, J.R., Seifert, R.A., Soriano, P., and Bowen-Pope, D.F. 1998. Chimaeric analysis reveals role of Pdgf receptors in all muscle lineages. Nat. Genet. 18: 385-388.

Crosby, J.R., Tappan, K.A., Seifert, R.A., and Bowen-Pope, D.F. 1999. Chimera analysis reveals that fibroblasts and endothelial cells require platelet-derived growth factor receptor $\beta$ expression for participation in reactive connective tissue formation in adults but not during development. Am. J. Pathol. 154: 1315-1321.

Dandre, F. and Owens, G.K. 2004. Platelet-derived growth factor-BB and Ets-1 transcription factor negatively regulate transcription of multiple smooth muscle cell differentiation marker genes. Am. J. Physiol. Heart Circ. Physiol. 286: H2042-H2051.

DeMali, K.A., Balciunaite, E., and Kazlauskas, A. 1999. Integrins enhance platelet-derived growth factor (PDGF)-dependent responses by altering the signal relay enzymes that are recruited to the PDGF $\beta$ receptor. J. Biol. Chem. 274: 1955119558.

Dong, J., Grunstein, J., Tejada, M., Peale, F., Frantz, G., Liang, W.-C., Bai, W., Yu, L., Kowalski, J., Liang, X., et al. 2004. VEGF-null cells require PDGFRa signaling-mediated stromal fibroblast recruitment for tumorigenesis. EMBO $\mathrm{J}$. 23: $2800-2810$.

Dvorak, H.F. 1986. Tumors: Wounds that do not heal. Similarities between tumor stroma generation and wound healing. N. Engl. J. Med. 315: 1650-1659.

Egeblad, M. and Z. Werb. 2002. New functions for the matrix metalloproteinases in cancer progression. Nat. Rev. Cancer. 2: $161-174$.

Enge, M., Bjarnegård, M., Gerhardt, H., Gustafsson, E., Kalen, M., Asker, N., Hammes, H.P., Shani, M., Fassler, R., and Betsholtz, C. 2002. Endothelium-specific platelet-derived growth factor-B ablation mimics diabetic retinopathy. EMBO J. 21: 4307-4316.

Fambrough, D., McClure, K., Kazlauskas, A., and Lander, E.S. 1999. Diverse signaling pathways activated by growth factor receptors induce broadly overlapping, rather than independent, sets of genes. Cell 97: 727-741.

Galvez, B.G., Matias-Roman, S., Yanez-Mo, M., SanchezMadrid, F., and Arroyo, A.G. 2002. ECM regulates MT1MMP localization with $\beta_{1}$ or $\alpha_{v} \beta_{3}$ integrins at distinct cell compartments modulating its internalization and activity on human endothelial cells. J. Cell Biol. 159: 509-521.

Galvez, B.G., Matias-Roman, S., Yanez-Mo, M., Vicente-Manzanares, M., Sanchez-Madrid, F., and Arroyo, A.G. 2004. Caveolae are a novel pathway for membrane-type 1 matrix metalloproteinase traffic in human endothelial cells. Mol. Biol. Cell 15: 678-687.

Gerhardt, H. and Betsholtz, C. 2003. Endothelial-pericyte interactions in angiogenesis. Cell Tissue Res. 314: 15-23.

Gingras, D., Bousquet-Gagnon, N., Langlois, S., Lachambre, M.P., Annabi, B., and Beliveau, R. 2001. Activation of the extracellular signal-regulated protein kinase (ERK) cascade by membrane-type-1 matrix metalloproteinase (MT1-MMP). FEBS Lett. 507: 231-236.

Goldbrunner, R.H., Bernstein, J.J., and Tonn, J.C. 1998. ECMmediated glioma cell invasion. Microsc. Res. Tech. 43: 250257.

Hellström, M., Kalen, M., Lindahl, P., Abramsson, A., and Betsholtz, C. 1999. Role of PDGF-B and PDGFR- $\beta$ in recruitment of vascular smooth muscle cells and pericytes during embryonic blood vessel formation in the mouse. Development 126: 3047-3055.

Hellström, M., Gerhardt, H., Kalen, M., Li, X., Eriksson, U.,
Wolburg, H., and Betsholtz, C. 2001. Lack of pericytes leads to endothelial hyperplasia and abnormal vascular morphogenesis. J. Cell Biol. 153: 543-553.

Hiraoka, N., Allen, E., Apel, I.J., Gyetko, M.R., and Weiss S.J. 1998. Matrix metalloproteinases regulate neovascularization by acting as pericellular fibrinolysins. Cell 95: 365-377.

Hobson, J.P., Rosenfeldt, H.M., Barak, L.S., Olivera, A., Poulton, S., Caron, M.G., Milstien, S., and Spiegel, S. 2001. Role of the sphingosine-1-phosphate receptor EDG-1 in PDGF-induced cell motility. Science 291: 1800-1803.

Hoch, R.V. and Soriano, P. 2003. Roles of PDGF in animal development. Development 130: 4769-4784.

Holmbeck, K., Bianco, P., Caterina, J., Yamada, S., Kromer, M., Kuznetsov, S.A., Mankani, M., Robey, P.G., Poole, A.R., Pidoux, I., et al. 1999. MT1-MMP-deficient mice develop dwarfism, osteopenia, arthritis, and connective tissue disease due to inadequate collagen turnover. Cell 99: 81-92.

Hotary, K., Allen, E., Punturieri, A., Yana, I., and Weiss, S.J. 2000. Regulation of cell invasion and morphogenesis in a three-dimensional type I collagen matrix by membrane-type matrix metalloproteinases 1, 2, and 3. J. Cell Biol. 149: 13091323.

Hotary, K.B., Yana, I., Sabeh, F., Li, X.-Y., Holmbeck, K., Birkedal-Hansen, H., Allen, E.D., Hiraoka, N., and Weiss, S.J. 2002. Matrix metalloproteinases (MMPs) regulate fibrin-invasive activity via MT1-MMP-dependent and -independent processes. J. Exp. Med. 195: 295-308.

Itoh, T., Ikeda, T., Gomi, H., Nakao, S., Suzuki, T., and Itohara, S. 1997. Unaltered secretion of beta-amyloid precursor protein in gelatinase A (matrix metalloproteinase 2)-deficient mice. J. Biol. Chem. 272: 22389-22392.

Jain, R.K. 2003. Molecular regulation of vessel maturation. Nat. Med. 9: 685-693.

Jiang, A., Lehti, K., Wang, X., Weiss, S.J., Keski-Oja, J., and Pei D. 2001. Regulation of membrane-type matrix metalloproteinase 1 activity by dynamin-mediated endocytosis. Proc. Nat1. Acad. Sci. 98: 13693-13698.

Kim, H.-R.C., Upadhyay, S., Li, G., Palmer, K.C., and Deuel, T.F. 1995. Platelet-derived growth factor induces apoptosis in growth-arrested murine fibroblasts. Proc. Natl. Acad. Sci. 92: 9500-9504.

Koshikawa, N., Schenk, S., Moeckel, G., Sharabi, A., Miyazaki, K., Gardner, H., Zent, R., Quaranta, V. 2004. Proteolytic processing of laminin-5 by MT1-MMP in tissues and its effects on epithelial cell morphology. FASEB J. 18: 364-366.

Labrecque, L., Nyalendo, C., Langlois, S., Durocher, Y., Roghi, C., Murphy, G., Gingras, D., and Beliveau, R. 2004. Src-mediated tyrosine phosphorylation of caveolin-1 induces its association with membrane type 1 matrix metalloproteinase. J. Biol. Chem. 279: 52132-52140.

Lehti, K., Lohi, J., Valtanen, H., and Keski-Oja, J. 1998. Proteolytic processing of membrane-type-1 matrix metalloproteinase is associated with gelatinase A activation at the cell surface. Biochem. J. 334: 345-353.

Lehti, K., Valtanen, H., Wickström, S.A., Lohi, J., and Keski-Oja, J. 2000. Regulation of membrane-type-1 matrix metalloproteinase activity by its cytoplasmic domain. J. Biol. Chem. 275: 15006-15013.

Leveen, P., Pekny, M., Gebre-Medhin, S., Swolin, B., Larsson, E., and Betsholtz, C. 1994. Mice deficient for PDGFB show renal, cardiovascular, and hematological abnormalities. Genes \& Dev. 8: 1875-1887.

Li, J., Kim, Y.-N., and Bertics, P.J. 2000. Platelet-derived growth factor-stimulated migration of murine fibroblasts is associated with epidermal growth factor receptor expression and tyrosine phosphorylation. J. Biol. Chem. 275: 2951-2958. 
Lindahl, P., Johansson, B.R., Leveen, P., and Betsholtz, C. 1997. Pericyte loss and microaneurysm formation in PDGF-B-deficient mice. Science 277: 242-245.

Lindblom, P., Gerhardt, H., Liebner, S., Abramsson, A., Enge, M., Hellstrom, M., Backstrom, G., Fredricksson, S., Landegren, U., Nystrom, H.C., et al. 2003. Endothelial PDGF-B retention is required for proper investment of pericytes in the microvessel wall. Genes \& Dev. 17: 1835-1840.

Mays, P.K., J.E. Bishop, and G.J. Laurent. 1988. Age-related changes in the proportion of types I and III collagen. Mech. Ageing Dev. 45: 203-212.

Morikawa, S., Baluk, P., Kaidoh, T., Haskell, A., Jain, R.K., and McDonald, D.M. 2002. Abnormalities in pericytes on blood vessels and endothelial sprouts in tumors. Am. I. Pathol. 160: $985-1000$.

Mu, D., Cambier, S., Fjellbirkeland, L., Baron, J.L., Munger, J.S., Kawakatsu, H., Sheppard, D., Broaddus, V.C., and Nishimura, S.L. 2002. The integrin $\alpha v \beta 8$ mediates epithelial homeostasis through MT1-MMP-dependent activation of TGFß1. J. Cell Biol. 157: 493-507.

Nicosia, R.F., Nicosia, S.V., and Smith, M. 1994. Vascular endothelial growth factor, platelet-derived growth factor, and insulin-like growth factor-1 promote rat aortic angiogenesis in vitro. Am. J. Pathol. 145: 1023-1029.

Oblander, S.A., Zhou, Z., Galvez, B.G., Starcher, B., Shannon, J.M., Durbeej, M., Arroyo, A.G., Tryggvason, K., and Apte, S.S. 2005. Distinctive functions of membrane type 1 matrixmetalloprotease (MT1-MMP or MMP-12) in lung and submandibular gland development are independent of its role in pro-MMP-2 activation. Dev. Biol. 277: 255-269.

Owens, G.K., Kumar, M.S., and Wamhoff, B.R. 2004. Molecular regulation of vascular smooth muscle cell differentiation in development and disease. Physiol. Rev. 84: 767-801.

Paik, J.-H., Skoura, A., Chae, S.-S., Cowan, A.E., Han, D.K., Proia, R.L., and Hla, T. 2004. Sphingosine 1-phosphate receptor regulation of $\mathrm{N}$-cadherin mediates vascular stabilization. Genes \& Dev. 18: 2392-2403.

Ratnikov, B.I., Rozanov, D.V., Postnova, T.I., Baciu, P.G., Zhang, H., DiScipio, R.G., Chestukhina, G.G., Smith, J.W., Deryugina, E.I., and Strongin, A.Y. 2002. An alternative processing of integrin $\alpha_{\mathrm{v}}$ subunit in tumor cells by membrane type-1 matrix metalloproteinase. J. Biol. Chem. 277: 73777385.

Rozanov, D.V., Hahn-Dantona, E., Struckland, D.K., and Strongin, A.Y. 2004. The low density lipoprotein receptor-related protein LRP is regulated by membrane type- 1 matrix metalloproteinase (MT1-MMP) proteolysis in malignant cells. $J$. Biol. Chem. 279: 4260-4268.

Sabeh, F., Ota, I., Holmbeck, K., Birkedal-Hansen, H., Soloway, P., Balbin, M., Lopez-Otin, C., Shapiro, S., Inada, M., Krane, S., et al. 2004. Tumor cell traffic through the extracellular matrix is controlled by the membrane-anchored collagenase MT1-MMP. J. Cell Biol. 167: 769-781.

Saharinen, P. and Alitalo, K. 2003. Double target for tumor mass destruction. J. Clin. Invest. 111: 1277-1280

Schneller, M., Vuori, K., and Ruoslahti, E. 1997. $\alpha \mathrm{v} \beta 3$ integrin associates with activated insulin and PDGF $\beta$ receptors and potentiates the biological activity of PDGF. EMBO $J$. 16: $5600-5607$.

Seiki, M., Koshikawa, N., and Yana, I. 2003. Role of pericellular proteolysis by membrane-type I matrix metalloproteinase in cancer invasion and angiogenesis. Cancer Metastasis Rev. 22: $129-143$.

Soriano, P. 1994. Abnormal kidney development and hematological disorders in PDGF $\beta$-receptor mutant mice. Genes \& Dev. 8: 1888-1896.
Sounni, N.E., Roghi, C., Chabottaux, V., Janssen, M., Munaut, C., Maquoi, E., Glavez, B.G., Gilles, C., Frankenne, F., Murphy, G., et al. 2004. Up-regulation of vascular endothelial growth factor-A by active membrane-type 1 matrix metalloproteinase through activation of Src-tyrosine kinases. J. Biol. Chem. 279: 13564-13574.

Stegemann, J.P. and Nerem, R.M. 2003. Altered response of vascular smooth muscle cells to exogenous biochemical stimulation in two- and three-dimensional culture. Exp. Cell Res. 283: 146-155.

Takino, T., Miyamori, H., Watanabe, Y., Yoshioka, K., Seiki, M., and Sato, H. 2004. Membrane type 1 matrix metalloproteinase regulates collagen-dependent mitogen-activated protein/extracellular signal-related kinase activation and cell migration. Cancer Res. 64: 1044-1049.

Tallquist, M. and Kazlauskas, A. 2004. PDGF signaling in cells and mice. Cytokine Growth Factor Rev. 15: 205-213.

Tallquist, M.D., Klinghoffer, R.A., Heuchel, R., Mueting-Nelson, P.F., Corrin, P.D., Heldin, C.-H., Johnson, R.J., and Soriano, P. 2000. Retention of PDGFR- $\beta$ function in mice in the absence of phosphatidylinositol 3 '-kinase and phospholipase C $\gamma$ signaling pathways. Genes \& Dev. 14: 3179-3190.

Tallquist, M.D., French, W.J., and Soriano, P. 2003. Additive effects of PDGF receptor $\beta$ signaling pathways in vascular smooth muscle cell development. PLOS Biol. 1: 288-299.

Yana, I. and Weiss, S.J. 2000. Regulation of membrane type-1 matrix metalloproteinase activation by proprotein convertases. Mol. Biol. Cell 11: 2387-2401. 


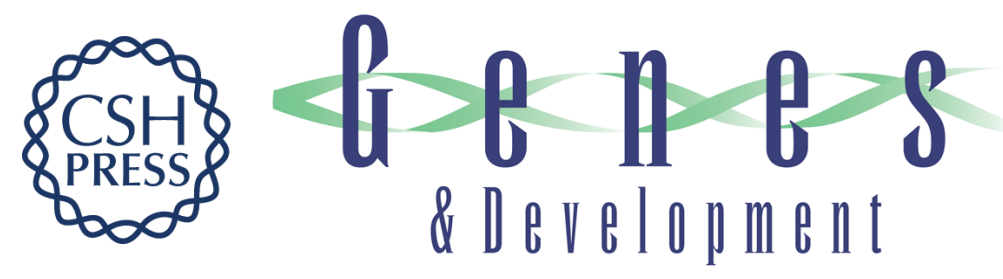

\section{An MT1-MMP-PDGF receptor- $\beta$ axis regulates mural cell investment of the microvasculature}

Kaisa Lehti, Edward Allen, Henning Birkedal-Hansen, et al.

Genes Dev. 2005, 19:

Access the most recent version at doi:10.1101/gad.1294605

References This article cites 64 articles, 35 of which can be accessed free at: http://genesdev.cshlp.org/content/19/8/979.full.htmI\#ref-list-1

License

Email Alerting Receive free email alerts when new articles cite this article - sign up in the box at the top Service right corner of the article or click here.

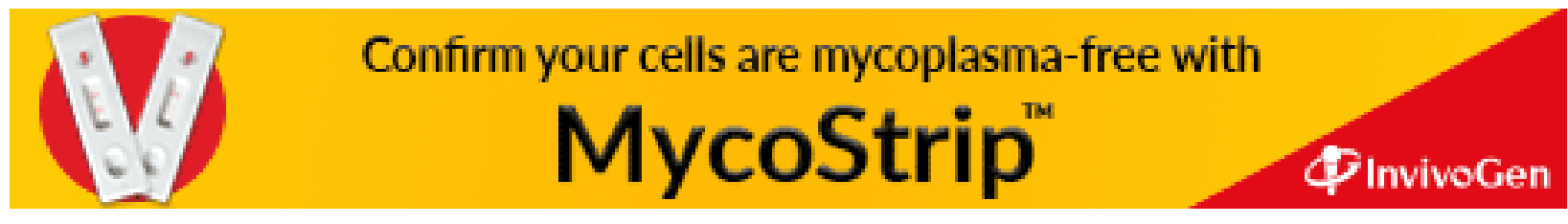

